\title{
PRESIDENT ANDREW JOHNSON IMPEACHED: THE FIRST PRESIDENTIAL IMPEACHMENT IN AMERICAN HISTORY
}

\author{
Tatiana V. Alentieva \\ Kursk State University, Kursk, Russian Federation
}

\begin{abstract}
Introduction. The article is devoted to the mechanism of impeachment procedure on the example of the first practical application of it in the history of the U.S. in relation to President Andrew Johnson. This created a necessary precedent in the further political struggle between the branches of government and has made the study of the history of the first presidential impeachment an urgent problem. Impeachment cases were brought against six subsequent presidents: Cleveland, Hoover, Truman, Nixon, Reagan, and G.W. Bush in the lower house of Congress. W. Clinton and D. Trump's impeachment was discussed in the Senate, but was not successful. Methods and materials. The article is based on materials from the American press as well as cartoons. The novelty of the source base is in combination of verbal and visual materials. The author used theoretical concepts developed within the framework of interdisciplinarity. The problem-chronological approach was the methodological basis of the research. In American historiography, Johnson is regarded as the "worst" President in U.S. history. However, the debate over the legitimacy of the first impeachment of a President in U.S. history has not subsided until now. In American studies, the impeachment of Andrew Johnson has not been specifically considered. Analysis. The conflict between the President and Congress was caused by the Reconstruction policy. The confrontation between the two branches of government led to impeachment. The President was charged in connection with the dismissal of Secretary of War E. Stanton, which was a violation of the Tenure of Office Act. The article examines how the impeachment procedure was implemented by Congress and why it failed. Results. Despite the failure, the first impeachment of a President in the history of the United States showed the effectiveness of the "checks" and "balances" mechanism in implementing the principle of separation of powers. It has become a deterrent to the relationship between the President and Congress.
\end{abstract}

Key words: history of the United States, $19^{\text {th }}$ century, the US Constitution, impeachment, Radical Republicans, Reconstruction of the South, Andrew Johnson.

Citation. Alentieva T.V. President Andrew Johnson Impeached: The First Presidential Impeachment in American History. Vestnik Volgogradskogo gosudarstvennogo universiteta. Seriya 4. Istoriya. Regionovedenie. Mezhdunarodnye otnosheniya [Science Journal of Volgograd State University. History. Area Studies. International Relations], 2021, vol. 26, no. 4, pp. 212-221. DOI: https://doi.org/10.15688/jvolsu4.2021.4.18

УДК 94(73).081

Дата поступления статьи: 28.04.2020

ББК 63.3(7)

Дата принятия статьи: 25.05.2020

\section{ИМПИЧМЕНТ ПРЕЗИДЕНТА ЭНДРЮ ДЖОНСОНА: ПЕРВАЯ ПРАКТИКА ПРИМЕНЕНИЯ В ИСТОРИИ США}

\author{
Татьяна Викторовна Алентьева \\ Курский государственный университет, г. Курск, Российская Федерация
}


имел. Статья основана на материалах американской прессы, также привлекались карикатуры. Новизна источниковой базы заключается в сочетании вербальных и визуальных материалов. Автор использовал теоретические концепции, разработанные в рамках междисциплинарности. Методологической основой исследования стал проблемно-хронологический подход. В американской историографии Джонсон рассматривается как «наихудший» президент в истории США. Однако дискуссии по поводу правомерности первого в истории США импичмента в отношении Президента не утихают до сих пор. В отечественной американистике импичмент Эндрю Джонсона специально не рассматривался. Причиной конфликта между Президентом и Конгрессом послужила политика Реконструкции. Противостояние двух ветвей власти привело к импичменту. Обвинение Президенту было выдвинуто в связи с отстранением от должности военного министра Э. Стэнтона, что явилось нарушением Закона о пребывании в должности. В статье рассматривается, как процедура импичмента была реализована Конгрессом и почему она потерпела неудачу. Несмотря на неудачу, первый в истории США импичмент в отношении Президента показал действенность механизма «сдержек» и «противовесов» в реализации принципа разделения властей. Он стал сдерживающим фактором в отношениях Президента и Конгресса.

Ключевые слова: история США, ХІХ век, Конституция США, импичмент, радикальные республиканцы, Реконструкция Юга, Эндрю Джонсон.

Цитирование. Алентьева Т. В. Импичмент Президента Эндрю Джонсона: первая практика применения в истории США // Вестник Волгоградского государственного университета. Серия 4, История. Регионоведение. Международные отношения. - 2021. - Т. 26, № 4. - С. 212-221. - (На англ. яз.). - DOI: https://doi.org/ 10.15688/jvolsu4.2021.4.18

Introduction. The relevance of the problem of constitutional removal from office of the highest official is surely the most important mechanism for implementing the principle of separation of powers and implementing democratic governance in practice. In this regard, the US experience is very interesting and instructive. Impeachment proceedings against a top official (President) are provided for in the US Constitution in article 2, section 4 . It is implemented in two stages. The grounds for impeachment are "high treason, bribery, and other serious crimes and offenses" [4, p. 37]. The first stage is the initiation of impeachment proceedings by the lower house of Congress - the House of Representatives. Here it is enough to gather a simple majority to initiate the process. The second stage is the consideration of the case in the Senate. Here, the impeachment procedure resembles a court hearing and is conducted under the auspices of the Supreme Court. Impeachment plays a crucial role as a "check" on Executive power in the constitutional system of separation of powers. In the history of the United States, there have been 3 cases of instigation and impeachment proceedings against a top official - the President.

Andrew Johnson became the first US President to be impeached. It is ture that it did not come to a conviction, but the procedure itself was important in the confrontation between the two branches of government: the Executive and the Legislative. Impeachment charges were subsequently brought by the lower house of Congress against G. Cleveland, H. Hoover, H. Truman, R. Reagan, and G. Bush, Jr. The threat of impeachment forced President R. Nixon to resign in 1974. In 1998, the W. Clinton sex scandal with M. Lewinsky became an occasion for a political confrontation between the President and Congress, but it did not come to a condemnation, the votes of senators were divided exactly in half: 50 against 50. Initiation of impeachment proceedings against the current President D. Trump was initiated on September 24, 2019 by the speaker of the Lower House, N. Pelosi, a supporter of the Democratic party. The charges against Trump were related to the White House's Ukrainian policy. On December 18, 2019 the House of Representatives voted on two charges against D. Trump - "abuse of power" and "obstructing a congressional investigation". On February 5, 2020, at the end of the consideration of the charges in the Senate, Trump was acquitted on both counts, as he failed to get $2 / 3$ of the votes necessary to convict the President. Johnson's story served as a lesson for subsequent heads of state. Thus, for the first time in American history, the impeachment of a top official created the necessary precedent and now plays the stabilizing role in the system of checks and balances, and continues to influence the political sphere of the United States. 
The purpose of the article is for the first time in Russian historiography to consider the reasons and course of the first impeachment trial in the history of the United States against President A. Johnson, as well as to analyze its significance for the US constitutional system.

Methods and materials. Consideration of the problem requires a dialectical approach and adherence to the principles of objectivity and historicism, as well as the use of special methods of historical research. The historical and biographical method allowed us to identify and analyze Johnson's life path, revealing his personal qualities in the course of psychohistory. The historical and genetic method made it possible to identify the causes, circumstances and factors that influenced the initiation of impeachment proceedings, as well as to study the dynamics of the political process and the role of chance in the development of events. In the context of the retrospective method, one can better understand the significance of the impeachment procedure for modern democracies. The ideographic method allowed us to consistently describe the process of political struggle, the result of which was an attempt to remove the President from office. Currently, any historical research is in the field of interdisciplinarity, so in order to understand the essence of what is happening, it is necessary to use the methods of political science, sociology, psychology, and jurisprudence.

The materials of the US Congress, published in full in the Congressional Globe are the sources for writing this article. Their study makes it possible to identify all aspects of Johnson's impeachment, including the debate and voting procedure. The work involves periodicals: Harper's Weekly, New York Tribune, New York Times, The Nation. Press materials make it possible to understand the public reaction to the events. Visual sources have become a valuable aid - political cartoons that represented politicians and their activities in a grotesque way and have allowed us to better understand what shortcomings of the President were mocked by artists.

In Russian American studies, Johnson's impeachment was not considered. In American historiography, Johnson is considered the "worst", "accidental" President in the history of the United States, so he is not as popular as other owners of the White House. Nevertheless, the figure of the $17^{\text {th }}$ President did attract the attention of biographers. In different periods, many detailed biographies appeared. Among them, it is worth highlighting both apologists and critics; the position of researchers is mainly determined by their attitude to the Radical Reconstruction. In the $1929 \mathrm{~s}-1930 \mathrm{~s}$, apologetic biographies of the $17^{\text {th }}$ President appeared, praising his "self-made-man" phenomenon and moderation in politics $[6 ; 18 ; 32$; 43]. According to these authors, Johnson was a humane, enlightened, and liberal statesman who waged a courageous fight for the Constitution and democracy against insidious and unscrupulous radicals driven by vindictive hatred of the South and political intolerance.

Since the 1960s, historians have focused on the situation of African-Americans as a central issue of the Reconstruction. These authors considered Johnson a saboteur of radical efforts to improve the fate of freedmen. Thus, the historian E. McKitrick showed him as a narrowminded, vindictive and stubborn man who thwarted the post-war reunification of the North and South [17].

Of course, the most attention of researchers was drawn to the impeachment process. A number of historians considered it a sad mistake, and the miscalculations of the Johnson administration were explained by the opposition of radicals [16;19]. The opposite view was to justify the actions of radicals and recognize impeachment as a necessary measure. M. Le Benedict argued that the impeachment of Johnson was a justified and necessary step to strengthen democracy [7]. The position adopted by H.L. Trefousse and Ch. Hearn is similar [13; 40; 41]. Historian and lawyer, African-American woman A. GordonReed believes that Johnson was not at all suitable for the complex tasks of the Reconstruction. She claimes that the failures of this President were due to "his preternatural stubbornness, his mean and crude racism" [12, p. 144]. The events related to the impeachment are described in detail in the form of popular fiction by historians and writers, such as N. Gerson, D. Stewart, B. Wineapple [11; 31; 42].

Analysis. Johnson became President by accident - as a result of the assassination of the $16^{\text {th }}$ President. On April 14, 1865, Lincoln was killed by actor J. Booth during a performance at 
Ford's theater. His Vice-President, A. Johnson, became President according to the Constitution.

Andrew's ascent to political Olympus was difficult enough. He stressed repeatedly that he was able to put into practice the American dream of a "self-made man": to be born in a "log cabin", to achieve the highest office in the country, to become President.

Born in Raleigh, in the southern state of North Carolina, to a poor white family, he seemed to have no chance of making a meteoric political career. Because of the family's poverty, he never attended school. Mastering the skill of a tailor allowed him to "stand out of the crowd". He moved to Western Tennessee. Here he got a family, became a successful businessman, engaged in self-education, and took the first steps in a political career. Having become rich, he bought himself slaves, in all he had ten of them [41, p. 31]. His political career was very favorable. Joining the Jacksonian Democrats, he successfully advanced through the stages of his political career. Starting as a representative in the state legislature, he was elected to the lower house of Congress in 1843, and served as Governor of Tennessee in 1853-1857, then as a Senator from that state. During the secession period, he remained a loyal supporter of the Union and did not leave his post in the Senate. During the Civil War, he was appointed military Governor of Tennessee with the rank of Brigadier General [26, p. 289].

In 1864, in the presidential election, he was paired with A. Lincoln as Vice President, despite belonging to the War Democrats. The Republicans hoped to strengthen their positions with this alliance [5, p. 402].

Becoming President after the end of the cruel Civil War, Johnson developed his plan to return the rebellious southern states to the Union, which was called "Presidential Reconstruction". His program offered amnesty to all those who took the oath of allegiance to the Union, except for those who owned property worth more than 20 thousand dollars [27, p. 355]. The latter had to personally apply to the President with petitions, which flattered the former "poor white man". To be readmitted to the Union, the states had to ratify the $13^{\text {th }}$ amendment, which abolished slavery. Meanwhile, local elections everywhere resulted in victories for Democrats and former confederates. A number of southern states adopted black codes requiring African-Americans to work on plantations under conditions that did not differ much from their former status as slaves. In December 1865, a secret organization of white racists, the $\mathrm{Ku}$ Klux Klan, was created to intimidate and kill African-Americans.

Famous cartoonist T. Nast reflected the negative consequences of the presidential policy in the cartoon "Reconstruction as it works". In the central scene, the artist used a Shakespearean motif, as he often did, depicting Johnson as an evil Iago plotting against the heroic Othello (the moor). Nast portrayed the main black hero as a wounded Union veteran who was denied his just and deserved place in American political life. At the top center, Nast placed scenes depicting a slave auction and flogging, emphasizing the continuity between the pre- and post-war South. At the top left and right, he included images of race riots in Memphis and New Orleans as symbols of constant and appalling violence against black people [1, p. 351].

The political establishment in the North was represented by various groups. Moderate Republicans sought to keep Democrats out of power at the national level, but they did not want African-American suffrage. The Northern Democrats favored the unconditional restoration of the southern states to the Union. Radical Republicans sought the right to vote and other civil rights for African-Americans. Some newspapers in the northern states began campaigning for their voting rights. The New York Times wrote: “...it would be better for Grant to surrender to Lee than to allow a state of affairs where Negroes are not allowed to vote" [20, p. 4]. The Nation argued: "by denying Negro suffrage, we make fools of ourselves every time we talk about democratic principles" [37, p. 4].

The congressmen refused to recognize the election of southern representatives as legitimate, and established a Committee to recommend new Reconstruction laws. There were passed a law that expanded the rights of the Freedmen's Bureau as well as the first African-American Civil Rights Act. However, Johnson vetoed it. The President enjoyed his right to "put congressmen in their place". He vetoed a total of 29 times during his presidency, while his predecessor Lincoln only 7 times [10, pp. 248-249]. 
On February 22, 1866, George Washington's birthday, Johnson delivered an impromptu speech to his supporters. He mentioned himself more than 200 times in his speech and accused his political opponents of not wanting to restore the Union as quickly as possible, refusing to extend the hand of friendship to southerners on his terms. When the crowd demanded their names, Johnson named T. Stevens, Ch. Sumner, and W. Phillips, and even accused them of plotting to kill him. Republicans regarded this address as a declaration of war. The New York Tribune called Johnson a "Judas" and a "drunken tailor" [21, p. 4], and Harper's Weekly considered his attacks on radicals "disgusting, offensive, unprecedented in the history of the country" [39, p. 147].

Despite persistent calls from moderates to sign the Civil Rights Act, Johnson strongly opposed it, vetoing it. The historian E. Foner considered this step of the President as "the most disastrous miscalculation in his political career" $[10$, p. $250-$ 251]. D. Stewart considered the veto "a strategic mistake that set the tone of eternal confrontation with Congress" [31, p. 53]. The veto was overcome by congressmen, for the first time in the history of the United States, such a thing was done on an important, and not a minor bill [9, p. 211].

Congress initiated the adoption of the $14^{\text {th }}$ amendment to the Constitution, according to which any person born in the United States received citizenship. Male persons were guaranteed voting rights, "excluding persons deprived of the right to vote for participation in a riot or criminal offenses" [4, pp. 43-44].

Both houses passed the Freedmen's Bureau Act for the second time, and again the President vetoed it, and the veto was again overturned. Cartoons, mostly by T. Nast, constantly and sharply ridiculed the activities of the $17^{\text {th }}$ President. One of them was devoted to numerous presidential vetoes. It shows Johnson on the steps of the White House kicking out a box of law. In another of his cartoons, Nast depicts the President as King Andy, sitting on a throne, with a crown on his head, a scepter and an orb in his hands. Next to him, Secretary of State W. Seward, as his grand vizier, told him what to do and who should be beheaded [1, pp. 342-344].

With the support of the President, the southerners strongly opposed the ratification of the $14^{\text {th }}$ amendment. In response, the joint congressional Commission issued a series of laws that initiated the Radical Reconstruction of the South. The former rebel states were divided into 5 military districts. The restoration of civil government in them was provided for by the convocation of constitutional conventions, whose task was to create new authorities capable of guaranteeing suffrage for former slaves and ratifying the $14^{\text {th }}$ amendment. The President was deprived of the right to pardon former rebels. All voters were required to take the oath of allegiance to the Union $[2$, p. $95 ; 22$, p. $4 ; 38$, p. $83 ; 28$, p. 51 ; 30, p. 547].

Based on the acts of military reconstruction, the right to vote was given to about 1 million black people (up to $75 \%$ of them illiterate) and 1 million white people (up to $30 \%$ illiterate), up to 200 thousand confederates were deprived of this right. In 1867, 735,000 African-Americans and 635,000 white people participated in the election of constitutional conventions, which became an important event in the history of Reconstruction. For the first time in the South, black people (43\% of the population) participated in the official bodies that determined the fate of this region. They received up to $28 \%$ of the seats in the constitutional conventions convoked in the first half of 1868 , promoting the "Radical Reconstruction" on the ground [3, p. 95].

Attempts to reach a compromise failed, and a political war broke out between the Republicans, on the one hand, and Johnson, along with his Northern and Southern democratic allies, on the other. The battleground was the Congressional elections of 1866, when the southern states were not yet eligible to vote. Republicans won a landslide victory, increasing their majority in Congress by two-thirds, in the Senate they had a ratio of 42 to 12 against the Democrats, and in the House of Representatives 143 to 49. With a constitutional majority, they could now easily overcome the presidential veto [40, p. 271].

On March 2, 1867, Congress passed the Tenure of Office Act despite the President's veto. With his help, congressmen wanted to protect the Secretary of War, the radical Republican E. Stanton, Lincoln's appointee. Nevertheless, Johnson dismissed Stanton and appointed Major General L. Thomas to his position. Thomas personally handed the notice of dismissal to Stanton. Instead of leaving the office, the latter 
barricaded himself inside and ordered Thomas's arrest. He informed the speaker of the House of Representatives, S. Colfax, and the President Pro tempore of the Senate, B. Wade, of the situation $[29$, p. 51$]$.

The President's conflict with Congress became inevitable. The New York Tribune stated: "Mr. Johnson's quarrel with Congress was predetermined and pre-planned; it was caused by his determination to break with the Republicans and declare war on them. All of Mr. Johnson's efforts are aimed at preventing congressional Reconstruction" [25, p. 4]. So Stanton's resignation became a convenient reason for Republicans to begin the procedure of removing the President from office [24, p. 4].

An impeachment resolution prepared by T. Stevens and J. Bingham was introduced in the House of Representatives. The North's press largely approved of the radicals' actions. Editor H. Greeley wrote: "We wholeheartedly approve of the actions of the House of Representatives. If the Republican Party has, or has ever had, an enemy, in the highest degree, deadly and insidious, then his name is undoubtedly Johnson. He should be impeached for the good of the country, and people will say 'Amen"' [23, p. 4]. His position was shared by the editor of Harper's Weekly, W. Curtis, who noted: "If Johnson is removed from office, public confidence in both branches of government will only increase, while the man whose elevation was a deep humiliation for every self-respecting American will forever sink into Lethe" [33, p. 163].

Johnson could not be charged with treason or bribery. The concept of "other serious crimes and criminally punishable acts (misdemeanors)", also provided by the Constitution as a reason for impeachment, was rather vague. But it was that very charge, which radical Republicans decided to use. They believed that a violation of the Tenure of Office Act would be the basis for impeachment.

On February 24, 1868, the House of Representatives voted 126 to 47 (with 17 members not voting) in favor of a resolution to begin impeachment proceedings against the President for serious crimes and misdemeanors committed by him. On March 2, the House of Representatives passed 11 articles of impeachment against the President [14,pp. 1613-1619].
Article 1 stated that by removing Stanton from office, the President had committed a serious official misconduct. 127 congressmen voted for it and 42 were against it.

Article 2 charged the President with appointing L. Thomas as interim Secretary of War without congressional approval, which also qualified as a serious official misconduct. Approved: "yea" - 124, "nay" - 41.

Article 3 actually repeated the charge of the second article, emphasizing that the appointment of L. Thomas was illegal, since the position of Secretary of War was not vacant during the recess of the Senate. Approved: "yea" - 124, "nay" - 40.

Article 4 charged "intimidation and threats" against Stanton, the legitimate Secretary of War. Approved: "yea" - 117, "nay" - 40.

Article 5 actually repeated the charge formulated in the previous article with small variations. Approved: "yea" - 127, "nay" - 42.

Article 6 added to the previous charges that the President and L. Thomas conspired to "by force to seize, take, and possess the property of the United States in the Department of War". Approved: "yea" - 127, "nay" -42.

Article 7 charged the President with preventing Stanton from "holding a position to which he was lawfully appointed". Approved: "yea" - 127, "nay" - 42.

Article 8 dealt with the financial aspects of the problem. In it, the President was accused of intending "to take possession of the property of the United States in the War Department, to control the payment of money allocated for military purposes". Approved: "yea" - 127, "nay" -42.

Article 9 accused Johnson of trying to transfer the functions of the Secretary of War to the commander of the Washington military district, major General W. Emory. Approved: "yea" - 108, "nay"- 41 [15, pp. 1638-1642].

Thus, the first 9 articles related to the removal of E. Stanton from the post of Secretary of War and the appointment of L. Thomas the interim Secretary of War, as well as financial issues of the military Department, which was qualified by congressmen as serious official misconduct and only in the $9^{\text {th }}$ article referred to a serious crime. Voting on these articles shows certain cohesion among both Republicans and Democrats. 
Article 10 is much more interesting, as it cited long passages from speeches by A. Johnson, in which he tried, according to congressmen, to discredit their activities. It stated that the President "...did attempt to bring into disgrace, ridicule, hatred, contempt and reproach, the Congress of the United States... so hatred and contempt for It, weaken and destroy respect... openly and publicly... make and declare, with a loud voice, certain intemperate, inflammatory and scandalous harangues, and therein utter loud threats and bitter menaces against Congress". Then there were the most characteristic passages from the President's speeches, in which he threatened to expel his opponents from Congress and to veto all radical laws. Approved: "yea" 88, "nay" -44.

Article 11 accused the President of not recognizing the authority of the $40^{\text {th }}$ Congress on the grounds that it did not represent the southern states, and therefore Johnson denied that Congress the right to pass laws and amendments to the Constitution, which the congressmen considered a serious official misconduct. Approved: "yea" - 109, "nay"- 32 [15, p. 1642].

As we can see, articles 10 and 11 charged the President with disrespect for the Congress and even non-recognition of its powers. At the same time, it is obvious that these articles met with the least support of congressmen when voting. All these charges were just a pretext for impeachment; it was about the fate of the Reconstruction.

In general, the document was legally weak. Despite all his shortcomings and ill-considered actions, the President did not commit high treason, and although articles 6 and 8 hinted at financial irregularities, there were no facts cited to accuse the President of corruption. Almost all of the articles, with the exception of the ninth, referred to serious official misconduct, but not to crimes.

On March 4, 1868, 11 articles of charges were submitted to the Senate. The next day, it began its sessions as an impeachment court presided over by Chief Justice S. Chase. Then the senators were sworn in as jurors [10, p. 336; 36, p. 195].

On the advice of a lawyer, the President did not attend court sessions. The trial was held in public, and the Senate galleries were filled to capacity. The public interest was so great that the Senate issued entrance passes for the first time in its history. For each day of the trial, 1000 multi-colored tickets were printed, giving admission for one day [35, p. 21].

On March 30, after a short break, the hearing resumed. The session was opened by B. Butler with a three-hour accusatory speech, in which he referred to historical precedents from English history and proved the illegality of Stanton's dismissal. As an experienced lawyer and public speaker, he immediately elicited cheers from the audience. The climax was when Butler took a red-stained shirt from a bundle and, waving it in front of the audience, claimed that it belonged to a former slave, an employee of the Freedmen's Bureau, who had been brutally beaten by Ku Klux Klansmen. Thus a new expression appeared in the political lexicon: "waving a bloody shirt" [31, p. 207].

This symbolic gesture was approved by radical Republicans. Ch. Sumner, a staunch abolitionist, made a fiery speech in which he assured that the indictments of the House of Representatives were formal, and the root of the evil was the very position of the President in relation to the Reconstruction of the South. "This is one of the last great battles with slavery. Driven from these legislative chambers, driven from the field of war, this monstrous power has found a refuge in the Executive Mansion, where, in utter disregard of the Constitution and laws, it seeks to exercise its ancient far-reaching sway... No one can doubt it. Andrew Johnson is the impersonation of the tyrannical slave power. In him, she was alive again... He once declared himself the Moses of the colored race. Behold him now the Pharaoh. With such treachery in such a cause there can be no parley. Every sentiment, every conviction, every vow against slavery must now be directed against him. Pharaoh is at the bar of the Senate for judgment... And the sentence must be pronounced!" [8, pp. 463-474].

Sumner's position was supported by John Sherman, brother of the famous Civil War General W.T. Sherman. He also believed that the essence of the problem was the President's Reconstruction policy: "Instead of cooperating with Congress to implement the laws it passed, he obstructed and delayed their implementation, seeking to cause contempt for the laws and the legislature. With enormous powers, he neglects to protect unionists in the rebel states, so that murder, violence, and destruction of property occur throughout these 
states, while the political power is inactive". Speaking about the essence of the indictment, Sherman stressed that Stanton's removal from office was not just a gross violation of the law, but "...includes all the elements of a crime, namely: a violation of an explicit law, intentionally and intentionally committed with the intent to undermine the constitutional authority of the Senate... and this has a detrimental effect, which is that the President gets unlimited power over all officials" [8, p. 450].

Speaking in support of the prosecution, R. Yates stressed the importance of the impeachment procedure for the future of the country. "It is difficult to assess the importance of this test... This trial is aptly named the constitutional court... the precedents established by this trial will be cited as standard precedents in all such trials in the future" [8, p. 484].

A number of senators, including those belonging to the Republican Party, opposed the President's condemnation. Most of them believed that the indictment of the House of Representatives did not give grounds for removing the President from office. Grimes stated that the principle of presidential impeachment was unacceptable. "I cannot agree to destroy the harmonious work of the Constitution in order to get rid of an unacceptable President. Whatever my opinion of this man may be, I cannot afford to trifle with his high position" [8, p. 424].

The lack of evidence for the charges was mentioned in a speech by a moderate Republican, L. Trumbull. He bluntly stated that removing Stanton from office was not a "crime" and nothing in the President's behavior suggested a conspiracy to usurp power. He also argued that undermining the President's authority on insufficiently convincing grounds would play a bad role in the future fate of the country. "To condemn and depose the chief magistrate of a great country when his guilt is not apparent in the 11 articles of impeachment, and for insufficient reason, would be fraught with far greater danger to the future of the country than if Mr. Johnson were left in office for the remaining months of his term, with powers curtailed and limited, as has been done under recent legislation" [8, p. 420].

Quite emotional was the speech in defense of Johnson by Senator W. Grosbeck of Ohio: "He is a patriot! He may make mistakes, but he loves his country... no amount of testing could force him to change the Union... he is not capable of treason" [8, p. 310].

At the time of the trial, the Senate consisted of 54 members representing 27states (10 former Confederate States had not yet been re-admitted to representation in the Senate). An impeachment conviction required a two-thirds majority, in this case 36 votes. Of the 11 charges, only three articles were voted on: 2,3 and 11. Total: $35-$ "yea", 19 - "nay". The conviction failed by only one vote [8, pp. 410-412; 34, p. 350].

None of the seven Republicans who voted against impeachment was able to continue his political career, and their party members did not forgive their treachery. Johnson remained in office until the end of his term on March 4, 1869, although as a "lame duck", he had little influence on public policy. He had to give up the idea of re-election for a second term. The 1868 election was won by Civil War hero Ulysses S. Grant, who supported black suffrage. This allowed the Congress to continue the policy of Radical Reconstruction of the South, which ended with the adoption of the $15^{\text {th }}$ amendment to the US Constitution.

Results. The first impeachment of a top official in the history of the United States did not lead to the removal of President Johnson, and one vote was not enough to convict him. But it demonstrated the effectiveness of this procedure, since even an unsuccessful impeachment in terms of results led to a temporary change in the balance of the branches of power. In fact, the struggle between the President and Congress was over who would implement the Reconstruction policy and what measures. Despite the failure of impeachment, the institution of the presidency was weakened, and Congress secured a dominant position until at least the end of the $19^{\text {th }}$ century. A number of American historians rightly consider the Reconstruction of the South to be the final stage of the Second North American revolution. Impeachment brought Radical Reconstruction to its logical conclusion by passing the $15^{\text {th }}$ amendment to the Constitution, which secured voting rights regardless of race and color. This was the first impeachment of a Chief Executive in the history of the United States. With this in mind, subsequent presidents should have acted with an eye to Congress. This was a clear 
confirmation of the effectiveness of the system of "checks and balances" laid down by the Founding Fathers in the American Constitution, which made the separation of powers in the United States real, not formal.

\section{REFERENCES}

1. Alenteva T.V. Razyaschee oruzhie smeha. Amerikanskaya politicheskaya karikatura XIX veka (1800-1877) [A Striking Weapon of Laughter. American Political Caricature of the Nineteenth Century (18001877)]. Saint Petersburg, Aleteya Publ., 2020. 458 p.

2. Allen J. Rekonstruktsiya: Bitva za demokratiyu v SShA 1865-1876 [Reconstruction: The Battle for Democracy 1865-1876]. Moscow, Izd-vo inostrannoy literatury, $1963.273 \mathrm{p}$.

3. Sogrin V.V. Istoriya SShA [History of the United States]. Moscow, Mezhdunarodnyie otnosheniya Publ., 2020. 600 p.

4. Zhidkov O.A., ed. Soedinennye Shtaty Ameriki. Konstitutsiya i zakonodatelnye akty [The United States of America. Constitution and Legislative Acts]. Moscow, Progress Publ., Univers Publ., 1993. 768 p. June 25 .

5. Andrew Johnson. Harper's Weekly, 1864,

6. Beale H.K. The Critical Year: A Study of Andrew Johnson and Reconstruction. New York, Harcourt, Brace and Company, 1930. 454 p.

7. Benedict M.L. The Impeachment and Trial of Andrew Johnson. New York, Norton, 1999. 216 p.

8. Congressional Globe. Senate. $40^{\text {th }}$ Congress. $2^{\text {nd }}$ Session. Supplement to the Globe. Trial of Andrew Johnson. Washington, F. \& J. Rives \& George A. Bailey, $1868.526 \mathrm{p}$. April 6

9. Domestic Intelligence. Harper 's Weekly, 1867,

10. Foner E. Reconstruction: America's Unfinished Revolution. 1863-1877. New York, HarperCollins, 2002.690 p.

11. Gerson N.B. The Trial of Andrew Johnson. New York, Thomas Nelson, 1977. 159 p.

12. Gordon-Reed A. Andrew Johnson. New York, Times Books, 2011. 192 p.

13. Hearn Ch.G. The Impeachment of Andrew Johnson. New York, McFarland, 2012. 269 p.

14. Impeachment of the President. Congressional Globe. 40 ${ }^{\text {th }}$ Congress. $2^{\text {nd }}$ Session, 1868, March 2, vol. 39 .

15. Impeachment of the President. Congressional Globe. 40 ${ }^{\text {th }}$ Congress. $2^{\text {nd }}$ Session, 1868, March 3, vol. 39.

16. Mantell M.E. Johnson, Grant, and the Politics of Reconstruction. New York, Columbia University Press, 1973. 224 p.
17. McKitrick E. Andrew Johnson and Reconstruction. Oxford, Oxford University Press, $1988.533 \mathrm{p}$.

18. Milton G.F. The Age of Hate: Andrew Johnson and the Radicals. New York, Coward-McCann, 1930. $787 \mathrm{p}$.

19. Nash H.P., Jr. Andrew Johnson: Congress and Reconstruction. Plainsboro, New Jersey, Associated University Presses, $1972.170 \mathrm{p}$.

20. New York Times, 1865, June 10.

21. New York Tribune, 1866, February 24.

22. New York Tribune, 1866, February 23.

23. New York Tribune, 1868, February 19.

24. New York Tribune, 1868, January 15.

25. New York Tribune, 1868, January 16.

26. President Andrew Johnson. Harper's Weekly, 1865, May 13.

27. President Johnson's Amnesty Proclamation. Harper's Weekly, 1865, June 10.

28. Reconstruction Measures. Harper's Weekly, 1868, January 25.

29. Secretary Stanton's Restoration. Harper's Weekly, 1868, January 26.

30. Southern Reconstruction. Harper's Weekly, 1867, August 31.

31. Stewart D.O. Impeached: The Trial of President Andrew Johnson and the Fight for Lincoln's Legacy. New York, Simon \& Schuster, 2009. $464 \mathrm{p}$.

32. Stryker L.P. Andrew Johnson: A Study in Courage. New York, Macmillan, 1929.875 p.

33. The Impeachment. Harper's Weekly, 1868, March 14.

34. The Impeachment. Harper's Weekly, 1868, May 30.

35. The Impeachment Trial. Harper's Weekly, 1868, April 4.

36. The Impeachment Trial. Harper's Weekly, 1868, March 28.

37. The Nation, 1865, July 27.

38. The New Reconstruction Bill. Harper's Weekly, 1867, February 8.

39. The President's Speech. Harper's Weekly, 1866, March 10.

40. Trefousse H.L. Andrew Johnson: A Biography. New York, W.W. Norton \& Company, $1989.271 \mathrm{p}$.

41. Trefousse H.L. Impeachment of a President: Andrew Johnson, the Blacks, and Reconstruction. New York, Fordham University Press, 1999. 252 p.

42. Wineapple B. The Impeachers: The Trial of Andrew Johnson and the Dream of a Just Nation. New York, Random House, 2019. 576 p.

43. Winston R.W. Andrew Johnson: Plebeian and Patriot. New York, Henry Holt and Company, 1928. $549 \mathrm{p}$. 
T.V. Alentieva. President Andrew Johnson Impeached: The First Presidential Impeachment in American History

\section{Information About the Author}

Tatiana V. Alentieva, Doctor of Sciences (History), Professor, Department of World History, Kursk State University, Radishcheva St, 33, 305000 Kursk, Russian Federation, alenttv@mail.ru, https://orcid.org/0000-0002-3816-0494

\section{Информация об авторе}

Татьяна Викторовна Алентьева, доктор исторических наук, профессор кафедры всеобщей истории, Курский государственный университет, ул. Радищева, 33, 305000 г. Курск, Российская Федерация, alenttv@mail.ru, https://orcid.org/0000-0002-3816-0494 